Commentary

\title{
From the Garden City to the Smart City
}

\author{
Stephan Hügel \\ The Bartlett Centre for Advanced Spatial Analysis, University College London, London, W1T 4TJ, UK; \\ E-Mail: stephan.hugel.12@ucl.ac.uk
}

Submitted: 21 June 2017 | Accepted 29 June 2017 | Published: 23 August 2017

\begin{abstract}
It has been a century since the first Garden Cities at Welwyn and Letchworth were founded and, in the eyes of many, we have entered the age of the Smart City. This commentary briefly reflects upon the origins of Ebenezer Howard's vision in the slums of overcrowded, filthy London and the fire-traps of early 20th century Chicago before outlining some of the main contributing factors to its ultimate failure as an approach: the lack of a robust theory underpinning his ideas, a finance model which was unacceptable to the banks - leading to a compromise which robbed the more idealistic participants of any real power over their schemes-and finally, a dilution of Howard's vision by architects who were more focused on population density than on social reform. A parallel is then drawn between the weaknesses which afflicted the Garden City vision, and those which afflict current Smart City visions, a loose agglomeration of ahistorical techno-utopian imaginaries, whose aims almost invariably include optimising various measures of efficiency using large-scale deployments of networked sensors and cameras, linked to monolithic control rooms from which our shared urban existence is overseen. The evolution (or perhaps more accurately: alteration) of these concepts in response to criticism is then detailed, before some of the less well-known ideas which are now emerging are briefly discussed.
\end{abstract}

\section{Keywords}

garden city; smart city; urban technologies; utopias

\section{Issue}

This commentary is part of the issue "Smart Solutions for Sustainable Cities", edited by Tom Sanchez (Virginia Tech, USA), Ralph Hall (Virginia Tech, USA) and Nader Afzalan (Redlands University, USA)

(C) 2017 by the author; licensee Cogitatio (Lisbon, Portugal). This article is licensed under a Creative Commons Attribution 4.0 International License (CC BY).

\section{Introduction: The Bitter Cry of Outcast London}

Returning to London in 1876, Ebenezer Howard, an English clerk who had gone to the United States to work first as a farmer, and later as a journalist, having witnessed the rebuilding of Chicago following a major fire in the 1870 s, became convinced that a new departure was required in the planning and construction of cities. Dismaying at the overcrowded, impoverished, diseaseridden capital, and bitterly disappointed by Chicago rebuilding itself according to its previous shape, Howard set to work on a book which in its first edition would come to be titled To-Morrow.

Howard recognized that people did not want to live in the overcrowded, dirty, expensive cities of the late 19th century, their living conditions in these rapidlyexpanding metropolises having been vividly illustrated by publications such as Andrew Mearns's 1885 pamphlet,
The Bitter Cry of Outcast London (Mearns, 1883), and that their continuing influx was leading, increasingly, to the depopulation of country towns. However, Howard also recognized that life in the countryside held few attractions for city-dwellers. He was by no means alone in his desire for an alternative: as Schuyler points out (Parsons \& Schuyler, 2002, p. 4), "In the 1880s and 1890 s, more than 100 utopian and dystopian novels were published in Great Britain", many of them including "visions of a society in which the world enjoyed peace". Howard's thinking was greatly influenced by one of these books in particular, a work by the author Edward Bellamy, entitled Looking Backward, which Howard "swallowed whole", having been given a copy by a friend in 1888 , and which so moved him that he re-published it in Britain. In the foreword to a later edition of Howard's book-which was first published in 1898 and titled Tomorrow: A Peaceful Path to Real Reform-F. J. Osborn 
makes it clear that "Bellamy's two basic assumptionsthat technological advance could emancipate men from degrading toil, and that men are inherently co-operative and equalitarian-were the essence of Howard's own optimistic outlook, in which there was no proletarian resentment or class-bitterness, and not a trace of nostalgic anti-urbanism, anti-industrialism, or back-to-thelandism" (Howard, 1965, p. 20), and Howard himself stated this clearly: "Thus I was led to put forward proposals for testing out Bellamy's principles..." (Macfayden, 1970, p. 22).

\section{Utopias, and the Real World}

While Howard was certainly inspired by utopian conceptions of future cities, his own vision was firmly rooted in the real world, and in the real and urgent need for an alternative to the industrial cities of late Victorian Britain. This practical approach is evident in the structure of To-morrow itself: a great deal of the book is devoted to setting out exactly how one would go about constructing a "garden city", including detailed cost analyses. In these, Howard took inspiration from the model housing projects he had encountered in America. These projects were set up as limited-dividend companies, designed to appeal to investors who felt a moral kinship with ideals of social reform - the lower rate of return on this kind of development made them unattractive to traditional investors, but those who were interested were also actively engaged, often philanthropists, and thus more likely to publicly advocate for the idea, and bring their influence to bear. In Howard's proposals, the higher rental income which would accrue from the development would be used to amortize the initial investment, and later be directly used to fund cultural and social welfare projects (Parsons \& Schuyler, 2002, p. 6).

However, Howard's vision, of which the physical layout of the city was only a relatively small component, was never fully realized. In order to understand why this was the case, we must examine three aspects: his "theory", his plans for financing the garden city, and his ability to plan the physical form of the garden city. As Robert Beevers makes clear (Beevers, 1988, pp. 5, 17, 25-6, 31), the primary innovation of Howard's book was in its synthesis of a number of ideas which had hitherto been unconnected: a backlash against the 19th century industrial city, and a questioning of the economic system which underlay it; the emergence of science as a driver of progress, and in particular, of Darwinism as a driver of co-operation combined with a radicalism which was entirely separate from Marxist, revolutionary tendencies (Howard, 1965, p. 86); the 'colonization' of empty lands (which were in plentiful supply outside English cities at that time), inspired by the work of Alfred Marshall; the possibility of reclaiming some of the value of urban land-which had become unaffordable as a result of high migration to cities-through the use of popular legislation; the extension of ideas of co-operative land owner- ship to co-operative city management. However, while Howard managed to combine these disparate ideas in To-morrow, thus soliciting widespread (and, perhaps, unexpected) support, they never cohered into a more complete "theory", capable of answering critics and incorporating compromise and, ultimately, evolving. Howard's pragmatism and straightforward approach resulted in an idea whose underpinnings were ultimately too fragile to withstand their encounter with those who wished to pick and choose the most attractive aspects.

The second aspect is rather more straightforward, and concerns the matter of finance. Common land ownership was a central component of Howard's plan, and was to be incorporated at Letchworth in the form of leases whose value would increase in step with the size of the population and its own wealth. However, the Garden City Association, formed in 1899, was not able to raise sufficient capital to buy the land for Letchworth under these conditions, and was thus compelled to borrow the shortfall, which was considerable. However, the banks would not lend money for houses which could not be sold on the open market. The Association thus had no choice but to acquiesce to modified leases, and this had an additional effect of undoing the co-operative management structure of the garden city: it included a trust, which was to oversee the day-to-day management of the city in concert with its residents, and a board of directors, which was charged with raising the capital to build the city, and thus represented the interests of those who were financing it. As a result of the Association's use of the "standard" type of lease, the board of directors represented the interests of the banks, who had little or no interest in co-operating with, or deferring to the trust.

The final aspect is architectural: the garden city movement was attracting interest from architects, particularly those involved with the Arts and Crafts movement, whose interests dovetailed quite neatly with those of the founding members, and several of them actually joined the Association, encouraged by Howard. Of these, Barry Parker and Raymond Unwin would come to exert the most influence on the built realization of Howard's vision at Letchworth: Howard's physical vision of the garden city had been quite crude, its focus having been on social reform, and this was quickly 'rectified' by Unwin and Parker, who reformulated key aspects of Howard's initial ideas, especially those around urban density.

These changes, which together had significantly altered Howard's vision-even leading to a re-titling of subsequent editions of his book to Garden Cities of To-Morrow-coincided with a wider shift towards what was referred to, from 1905 onwards (Parsons \& Schuyler, 2002, p. 32) as "town planning". This movement incorporated key aspects of Howard's thinking, but it did not adopt his vision as a totality, and this rather more pragmatic approach led to the proliferation of what became known as "garden suburbs", rather than more garden cities. Thus, while Howard's vision launched a movement 
which soon took hold across the UK, and internationally not long after, his original intent-that of real social reform - was never quite realized. This is partially because Howard himself lacked the personal authority to champion his ideals in the face of competing imperatives, driven by financiers (no matter how socially-minded), architects, and town planners.

\section{The Age of the Smart City}

A century after the garden cities of Letchworth (ca. 1910) and Welwyn (ca. 1919), we have entered the age of the Smart City. No matter which definition, or combinations thereof we choose (Albino, Berardi, \& Dangelico, 2015), we must perforce acknowledge that it could not exist without the Garden City: it is both a radical new departure, and an idea whose conception has hitherto been firmly rooted in the kind of utopian thought (Datta, 2015a) which first motivated Howard to write To-morrow. However, it also exemplifies the problems which attended the rise of the garden city: the lack of a robust theoretical framework capable of assessing the quality of its own real-world output, which can be subjected to examination and critique, and which can evolve to accommodate change. Rather than inspiring us, the term largely remains a shorthand for any technological intervention in the city, and a purportedly useful term of art for mayors and municipalities wishing to portray themselves as progressive and technically competent, in a familiar reprise of the "densification" projects undertaken in the US in the late 1940s. In place of socially-minded reformers such as Robert Owen and Ebenezer Howard, we have neo-positivist projects run by venture capital companies such as Y Combinator Cities, and behaviourist projects run by technology giants, such as Google's Sidewalk Labs project in New York City's Hudson Yards (Mattern, 2016).

Instead of a new Civics (Geddes, 1904), or a considered study of the ways in which new technologies could thoughtfully be integrated into our urban fabric (Geddes, 1915; Mumford, 1991), there are hundreds of newspaper articles, blog posts, "charters", and best practice guides, many emphasizing the primacy of the "Smart Citizen", in a literal reading of Hill's exhortation that urban innovation must not begin with technology (Hill, 2013). This rhetoric would be ironic, were it not so damaging: in place of innovation which seeks to centre those demographics most likely to benefit (whether they are "citizens", or merely "people"), there is a largely uncritical enthusiasm for the seamless blending of technology with our urban built environment in order to monetise and secure it, with little thought given to the far-reaching secondary effects of these objectives, let alone their potential to reproduce or even exacerbate existing inequalities (Shaw \& Graham, 2016).

We have come some way towards attempts to categorise (Hollands, 2008), explain and historicise (Townsend, 2013), and critique (Greenfield \& Kim, 2013;
Wiig, 2016) the earliest and most egregious results of this tendency, such as New Songdo and Masdar City, and these critiques may in fact be having an appreciable effect: in Europe and North America, the tech companies involved in urban technology projects have refined their rhetoric, moving beyond the language of "disruption" so beloved in Silicon Valley and influenced by what Barbrook and Cameron termed "the Californian Ideology" (Barbrook \& Cameron, 1996). This tendency in turn has led to more nuanced critiques (Shelton, Zook, \& Wiig, 2014) of the more mundane, retrofit projects which are now seen in smaller cities, and some have begun to examine in more detail the most widely-touted improvements, such as the wide availability of Open Data, and purportedly increased participation in decision-making which lie at the heart of these (Cardullo \& Kitchin, 2017; Kitchin, 2013). In the global South (Watson, 2015) and in India, in particular, this more subtle tendency remains absent, the more considered interventions of the past (Goist, 1974) - though they are by no means without their critics (Rao-Cavale, 2016)-having given way to a technocratic megaproject incorporating the "twin logics of industrialisation and corporate urbanisation". Yet here, too, we find critical voices (Datta, 2015b).

\section{Beyond Familiar Paradigms}

Despite its ultimate failure, the influence of the Garden City remains with us today, and so it may be with current paradigms of the Smart City. Already, new ways of thinking about, and using technology in our cities are emerging: from "playable city" approaches such as that seen in Bristol, to re-purposing the Internet of Things-so often deployed unsuccessfully (Langendoen, Baggio, \& Visser, 2006) - as a tool for informal urbanism in Atlanta (DiSalvo \& Jenkins, 2017).

It may be that we are on the verge of a movement away from the neoliberal conception of urban technologies which enables what Srnicek terms "Platform Capitalism" (Hill, 2008; Srnicek \& De Sutter, 2017), while previously unfashionable approaches to inclusivity and community engagement such as technology networks (Smith, 2014), are once again being investigated as alternatives and complementary approaches to Living Labs. There have been calls for what Campbell refers to as a "radical incrementalism" (Campbell, 2016), echoing Ursula Franklin's entreaty that we should not shy away from large-scale technological interventions, but rather attempt to deploy them in ways that can be rolled back, adapted, and even undone if need be (Franklin, 1993). Plainly, we cannot know what the future holds, or how we will react to its challenges, in particular those engendered by climate change. What is clear, however, is that success lies in cooperation.

\section{Conflict of Interests}

The author declares no conflict of interests. 


\section{References}

Albino, V., Berardi, U., \& Dangelico, R. M. (2015). Smart cities: Definitions, dimensions, performance, and initiatives. Journal of Urban Technology, 22(1), 3-21. doi:10.1080/10630732.2014.942092

Barbrook, R., \& Cameron, A. (1996). The Californian ideology. Science as Culture, 6(1), 44-72. doi:10.1080/ 09505439609526455

Beevers, R. (1988). The garden city utopia: A critical biography of Ebenezer Howard. London: Macmillan.

Campbell, K. (2016). The radical incrementalist (How to build urban society in 12 lessons). UK: Massive Small (incorporating Urban Exchange).

Cardullo, P., \& Kitchin, R. (2017). Being a 'citizen' in the smart city: Up and down the scaffold of smart citizen participation (The Programmable City Working Paper 30). Retrieved from osf.io/preprints/socarxiv/v24jn

Datta, A. (2015a). New urban utopias of postcolonial India: 'Entrepreneurial urbanization'in Dholera smart city, Gujarat. Dialogues in Human Geography, 5(1), 3-22. doi:10.1177/2043820614565748

Datta, A. (2015b). A 100 smart cities, a 100 utopias. Dialogues in Human Geography, 5(1), 49-53. doi:10.1177/2043820614565750

DiSalvo, C., \& Jenkins, T. (2017). Fruit are heavy: A prototype public loT system to support urban foraging. In Proceedings of the 2017 Conference on Designing Interactive Systems, New York, USA (pp. 541-553). ACM. doi:10.1145/3064663.3064748

Franklin, U. (1999). The real world of technology. Toronto: House of Anansi.

Geddes, P. (1904). Civics: as applied sociology. Sociological papers, 1, 103-138.

Geddes, P. (1915). Cities in evolution: An introduction to the town planning movement and to the study of civics. London: Williams \& Norgate.

Goist, P. D. (1974). Patrick Geddes and the city. Journal of the American Institute of Planners, 40(1), 31-37.

Greenfield, A. (2013). Against the smart city (1.3. Edition). Do Projects.

Hill, D. (2008). The street as platform. City of Sound. Retrieved from http://www.cityofsound.com/blog/ 2008/02/the-street-as-p.html

Hill, D. (2013). On the smart city: Or, a 'manifesto' for smart citizens instead. City of Sound. Retrieved from http://www.cityofsound.com/blog/2013/02/on-thesmart-city-a-call-for-smart-citizens-instead.html

Hollands, R. G. (2008). Will the real smart city please stand up? Intelligent, progressive or en- trepreneurial?. City, 12(3), 303-320. doi:10.1080/ 13604810802479126

Howard, E. (1965). Garden cities of to-morrow. Cambridge, MA: MIT Press. (Original work published 1898)

Kitchin, R. (2013). Four critiques of open data initiatives. LSE: The impact blog, 27.

Langendoen, K., Baggio, A., \& Visser, O. (2006). Murphy loves potatoes: Experiences from a pilot sensor network deployment in precision agriculture. In 20th IEEE International Parallel and Distributed Processing Symposium, IPDPS 2006. IEEE. doi:10.1109/ IPDPS.2006.1639412

Macfayden, D. (1970). Sir Ebenezer Howard and the Town Planning Movement. Manchester: Manchester University Press.

Mattern, S. (2016). Instrumental city: The view from Hudson Yards, circa 2019. Places Journal.

Mearns, A. (1883). The bitter cry of outcast London: An inquiry into the condition of the abject poor. London: James Clarke \& Co.

Mumford, L. (1991). The city in history: Its origins, its transformations and its prospects. London: Penguin. (Original work published 1961)

Parsons, K. C., \& Schuyler, D. (2002). From garden city to green city: The legacy of Ebenezer Howard. Baltimore, MA: Johns Hopkins University Press.

Rao-Cavale, K. (2016). Patrick Geddes in India: Anticolonial nationalism and the historical time of "Cities in Evolution." Landscape and Urban Planning. doi:10.1016/j.landurbplan.2016.11.005

Shaw, J., \& Graham, M. (Eds.). (2016). Our Digital Rights to the City. Meatspace Press.

Shelton, T., Zook, M., \& Wiig, A. (2015). The 'actually existing smart city'. Cambridge Journal of Regions, Economy and Society, 8(1), 13-25. doi:10.1093/ cjres/rsu026

Smith, A. (2014). Technology networks for socially useful production. Journal of Peer Production, (5).

Srnicek, N., \& De Sutter, L. (2017). Platform capitalism (Theory redux). Cambridge, UK: Polity.

Townsend, A. M. (2013). Smart cities: Big data, civic hackers, and the quest for a new utopia. New York: W.W. Norton \& Company.

Watson, V. (2015). The allure of "smart city" rhetoric India and Africa. Dialogues in Human Geography, 5(1), 36-39. doi:10.1177/2043820614565868

Wiig, A. (2016). The empty rhetoric of the smart city: From digital inclusion to economic promotion in Philadelphia. Urban Geography, 37(4), 535-553. doi:10.1080/02723638.2015.1065686

\section{About the Author}

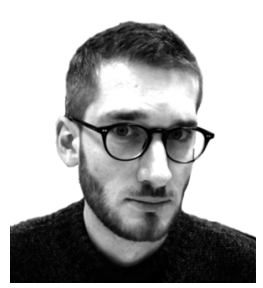

Stephan Hügel is a doctoral researcher at the UCL Centre for Advanced Spatial Analysis. He is interested in urban cybernetics, 20th century urban technology projects-particularly those of the 1980s and 1990s - and urban data visualisation. His research also explores the role of standards bodies and supranational unions in the evolution of urban socio-technical projects. 